\title{
Spiritual Well-Being and Religious Commitment in Explaining Customer Satisfaction and Loyalty in Sharia Banking
}

\author{
Arif Afendi \\ Universitas Islam Negeri Walisongo Semarang, Indonesia \\ email: arifafendi@walisongo.ac.id
}

\begin{abstract}
Abdul Ghofur
Universitas Islam Negeri Walisongo Semarang, Indonesia

email: abdul_ghofur@walisongo.ac.id
\end{abstract}

\begin{abstract}
This research aims to analyze the impact of spiritual well-being and religious commitment on customer satisfaction. And spiritual well-being, religious commitment, and customer satisfaction to customer loyalty. This research was quantitative with multiple linear regression. The data in this research was primary data with 165 banking customers. The sampling technique was non-probability sampling. The result of the research shows that There was a positive and significant effect of spiritual well-being and religious commitment to customer satisfaction. In addition, customer satisfaction has a positive and significant effect on customer loyalty. Another result shows spiritual well-being and religious commitment have a positive and significant effect on customer loyalty. This study provides information to sharia bank management to pay attention to religious and non-religious factors. For example, social, economic, educational, environmental, cultural factors, the magnitude of profit-sharing, completeness of facilities and infrastructure, and the sophistication of facilities such as ATMs, internet banking, and m-banking are considered in consideration finding customers. These factors contribute very dominantly to determine the level of satisfaction and loyalty of customers.
\end{abstract}

Keywords: Spiritual well-being; religious commitment; customer satisfaction; customer loyalty

Abstrak: Tujuan dari penelitian ini adalah untuk menguji pengaruh spiritual well-being dan komitmen agama terhadap kepuasan nasabah. Serta pengaruh spiritual well-being, komitmen agama dan kepuasan nasabah terhadap loyalitas nasabah. Jenis penelitian ini adalah kuantitatif dengan regresi linear berganda. Data dalam penelitian ini berupa data primer dengan 165 responden nasabah perbankan. Teknik pengambilan sampel dilakukan dengan menggunakan metode non probability sampling. Hasil penelitian ini menunjukkan bahwa adanya pengaruh positif dan signifikan spiritual well-being dan komitmen agama terhadap kepuasan nasabah. Pengaruh kepuasan nasabah terhadap loyalitas nasabah adalah positif dan signifikan. Selain itu pengaruh spiritual well being dan komitmen agama terhadap loyalitas nasabah adalah positif dan signifikan. Penelitian ini memberikan informasi kepada pihak manajemen bank 
syariah untuk memperhatikan faktor keagamaan serta non keagamaan, misalnya, faktor sosial, ekonomi, pendidikan, lingkungan, budaya, besarnya bagi hasil, kelengkapan sarana dan prasarana serta kecanggihan fasilitas seperti ATM, internet banking, m-banking sebagai pertimbangan dalam mencari nasabah, karena faktor ini memberikan kontribusi yang sangat dominan untuk menentukan tingkat kepuasan serta loyalitas nasabah.

Kata Kunci: Spiritual well-being; komitmen agama; kepuasan nasabah; loyalitas nasabah 


\section{Introduction}

Sharia banks are business organizations based on religion. Sharia banks by their originators expected to be a positive solution to the financial world order, especially banking. Such positive solutions can realize good morals, justice, and economic cooperation. Sharia bank business model uses religious teachings that regulate human relationships with others in muamalah activities. The main principle of sharia banks is not to run money businesses. Instead, Sharia banks are a forum to partner in business and provide money facilities to buy and sell. According to Kasmir (2007), With the significant potential of the Muslim population in Indonesia with religious and religious consumer characteristics and the existence of a fatwa haram bank interest from the Indonesian Ulama Council (MUI) in 2003 and with the enactment of Law No. 21 of 2008 on Sharia Banking, the development of Sharia banking has a solid legal basis.

Competition between financial institutions between sharia and conventional banks led to a new era in banking. The increasing number of financial institutions resulted in increasingly competitive and tight competition in the financial industry. In the current era, financial businesses, especially financial institutions of the sharia genre, are in high demand by the public. They believe that financial institutions based on religious or sharia principles will be better because they use a revenue-sharing system and use agreements following sharia and religious beliefs. The foundation that makes people increasingly entrust their funds to Islamic financial institutions. However, what must also consider is the quality of sharia financial institutions, whether it is by what they expect. Several factors affect the existence of Sharia banking in Indonesia, including spiritual well-being. Spiritual well-being conceptualization includes a two-dimensional construct consisting of vertical and horizontal dimensions. Religion as a vertical dimension shows that individual well-being relates to God (Allah) or the power of the Highest (religious well-being). Social psychology as a horizontal dimension focuses on

Economica: Jurnal Ekonomi Islam - Volume 12, Nomor 1 (2021) 
Arif Afendi and Abdul Ghofur

how well one adjusts to the community and its surrounding environment (existential well-being). These elements measure it, including subjective faith, self-satisfaction, personal holiness, subjective well-being, optimism, religious cynicism, and elitism (Perlman 1982).

In addition to spiritual well-being, a no less important factor is religious commitment. According to Sari (2011), religious commitment can create a better order of life despite different ethnicities, races, groups, and religions. Elements consist of religion as the basis of all life activities, taking time to understand religion and beliefs. Religion is the source of the meaning of life. Comfortable gathering with fellow believers, feeling comfortable active in religious organizations activities, actively developing information and making decisions in religious activities, and making financial contributions to religious organizations.

The next factor that can affect the existence of Sharia banking is customer satisfaction and loyalty. Customer satisfaction is a symbol or code that the customer usually uses to summarize an action or action that is visible related to a product or service. According to Kotler and Amstrong (2004), customer satisfaction is a classification where the product's performance (perceived performance) will follow the customer's expectations. In financial industries such as Sharia banking, customers place customer satisfaction criteria on service quality as the most important thing. According to Hansemark and Albinsson (2004), overall customer satisfaction shows the attitude towards service providers or emotional reactions to the difference between what customers expect and what they receive. According to Zeithaml and Bitner (2013), customer satisfaction results from customer evaluation of the product or service regarding whether the product the company created met customer expectations.

While customer loyalty is one of one's commitments to the company, repurposing products or services continuously and recommending them to others. According to Kotler and Amstrong (2004), customer loyalty will 
increase when customers are satisfied after making a purchase. Customer satisfaction is one of the leading indicators in shaping customer loyalty. At the same time, dissatisfaction will occur if the purchased product can not meet the desired expectations (Kotler and Amstrong 2004). According to Zeithaml and Bitner (2013), satisfaction is the response to the fulfillment of needs. Satisfaction is an assessment of the characteristics and advantages of a product or service.

Several previous studies on spiritual well-being and religious commitment have been conducted, including research conducted by Chusnah (2016) on the influence of religiosity, quality of service, and customer satisfaction on customer loyalty of bank Muamalat Indonesia's Magelang. The results of the study said that religiosity negatively affects customer loyalty. On the other hand, the quality of service and customer satisfaction positively and significantly affect customer loyalty. Meanwhile, Pangarso (2018) said that religiosity has a positive and significant effect on customer satisfaction but is not significant to customer loyalty. On the other hand, customer satisfaction has a positive and significant effect on Customer Loyalty.

According to El Junusi (2009) on The Influence of Islamic Product Attributes, Religious Commitment, Quality of Services And Trust in Customer Satisfaction and Loyalty of Sharia Banks (Bank Muamalat Semarang). The results said that the attributes of Islamic products, religious commitment, quality of services, and trust positively affect the satisfaction and loyalty of customer customers. Furthermore, according to Sungkawa (2014), religious commitment and beliefs have a positive and significant influence on customer satisfaction and loyalty. In addition, customer satisfaction can mediate the relationship between religious commitment and trust in customer loyalty.

According to Putri (2017), The Influence of Islamic Product Attributes, Religious Commitment, Quality of Services, and Trust in Sharia Banks' Customer Satisfaction. The results of said bring attributes of Islamic products, religious commitment, quality of services, and trust positively and 
significantly affect customer satisfaction. Religion contains everything of the best nature needed by humans to manage their purpose in life. Religion regulates and provides happiness and prosperity, justice, and what people need in dealing with others. Religious commitment is a form of adherence to religious teachings. That the higher the degree of religious commitment of the customer, the higher the satisfaction felt. According to Wallin Andreassen and Lindestad (1998) and Mohsan et al. (2011). The study results said that there is a positive and significant influence between Customer Satisfaction and Customer Loyalty. The more satisfied a customer will be with the products and services provided, they will be more loyal. Based on the above background and inconsistent research results, the purpose of this study is to retest whether spiritual well-being and religious commitment affect customer satisfaction and customer loyalty in Sharia banking.

\section{Literature review}

\section{Spiritual well-being}

Spiritual well-being is a good state, safe and peaceful. There are two approaches to understanding this concept-the first approach on happiness. The second approach is to develop human potential, the limitations of being a fully functional person, including a good way of thinking and a healthy physique (Paloutzian 1997). Spiritual well-being conceptualization includes a two-dimensional construct consisting of vertical and horizontal dimensions. Religion as a vertical dimension shows the well-being of individuals related to Allah. In contrast, the horizontal dimension relates to human sesame, how well one adjusts to the group and environment.

While spirituality, according to Perlman (1982), is a collection of meanings, values, transcendency, connecting, and becoming. Spiritual is selfenlightenment in achieving the goals and meanings of a better life and is essential to one's overall health and well-being. Spirituality is related to spirit and motivation, where spirituality has eternal truths related to the purpose of 
life. Spirituality is an expression of life perceived to be higher, more complex, or more integrated into their outlook on life. One aspect of spirituality is that it can improve their lives much better, be wiser, and have a clear direction of purpose.

\section{Religious commitment}

Commitment is a psychological state that broadly represents the experience of dependence on a relationship. Commitment is a form of longterm orientation in a relationship, including the desire to maintain that relationship. Companies experiencing a high level of competition demonstrate that their ability to create long-lasting relationships with customers depends on themselves and the competitors. Therefore, companies that differentiate from competitors will have a better chance of winning the competition and surviving. At the same time, religion contains everything that man needs to achieve his life goals. In addition, religion provides hope for goodness and well-being, morality, work ethic, justice, and what people need. Sari (2011) defines religious commitment as creating a life order in which there is no element of harming others (al-dhâlim) even though different religions, ethnic and gender. Analysis of religious relationships with a commitment to ethics does not stop at religious affiliation. There are several dimensions to measure religious commitment, such as visits to places of worship, participation in religious activities, and the level of personal religious beliefs (El Junusi 2009).

\section{Customer satisfaction}

According to Kotler and Amstrong (2004), customer satisfaction is a level where the product's assumption of performance (perceived performance) will follow customer expectations. At the same time, Oly Ndubisi (2004) said that customers place customer satisfaction criteria to the quality of services provided by banks as the essential thing in the Islamic banking industry. Levesque and McDougall (1996) explained that banking customer satisfaction attempts to satisfy bank customers by providing innovative ways. 
Parasuraman, Zeithaml, and Berry (1985) explained that the convenience and competitiveness of banks are two essential factors that affect overall and comprehensive customer satisfaction. According to Hansemark and Albinsson (2004), overall customer satisfaction shows the attitude towards service providers or emotional reactions to the difference between what customers expect and what they receive. According to Zeithaml and Bitner (2013), customer satisfaction is a way of evaluating a customer's product or service in terms of whether that product or service has met customer needs and expectations.

\section{Customer loyalty}

Customer loyalty is a form of customer commitment to the company that reflects a positive attitude by buying and recommending it to others. According to Kotler and Amstrong (2004), customer loyalty will increase when after making a purchase, they feel satisfied. Therefore, customer satisfaction is one of the essential benchmarks in determining customer loyalty. Customer satisfaction occurs if the purchased product exceeds their expectations or at least as desired. At the same time, dissatisfaction will occur if the selected product does not meet the expectations desired by customers (Kotler and Amstrong 2004).

According to Zeithaml and Bitner (2013), satisfaction is a response from consumers about fulfilling needs. Thus, satisfaction is an assessment of the characteristics or privileges of a product or service or the product itself that provides a level of consumer pleasure related to fulfilling consumer consumption needs. From the explanation above, customer satisfaction is the level of customer satisfaction when the results or performance of the product are by their expectations. 


\section{Hypothesis development}

\section{The effect of spiritual well-being on customer satisfaction}

Spiritual well-being is a good, safe, and peaceful situation; the concept of spiritual well-being includes a two-dimensional construct consisting of vertical and horizontal dimensions. Religion as a vertical dimension shows well-being individually related to Allah, while the horizontal dimension relates to fellow human beings. How well one adjusts to the groups and environments around them. According to Fatmah (2005) and Khan (2015), spiritual wellbeing and religiosity satisfy customers. Customers often associate choices about the principles of religious life in determining the products and services they will use. The religiosity of customers is very informed of their decisions in determining the choice of products or services used. This principle of religiosity will bind customers in line with their beliefs so that satisfaction with sharia values can make customer loyalty to continue to use the company's products or services. So that the higher the spiritual well-being level possessed by a customer, the higher the level of satisfaction.

H1: Spiritual well-being has a positive effect on customer satisfaction

\section{The effect of religious commitment on customer satisfaction}

According to Achsien (2000), religion contains everything that man best needs to cultivate the purpose of his life. Religion provides the ideal of happiness and well-being, morality, work ethic, justice management, and what people need in association with others and all elements of nature. Religious commitment is a form of adherence to religious teachings. For a Muslim, Islam is the way of life that governs all aspects of life. According to El Junusi (2009), Sari (2011), and Sungkawa (2014) stated that religious commitment has a positive and significant influence on customer loyalty means that the higher the degree of religious commitment that the customer has, the higher the satisfaction felt

$\mathrm{H} 2$ : religious commitment has a positive effect on customer satisfaction 


\section{The effect of customer satisfaction on loyalty customer}

According to Kotler and Amstrong (2004), customer satisfaction is how the product's performance (perceived performance) will follow customer expectations. At the same time, Oly Ndubisi (2004) said that customers place customer satisfaction criteria on the quality of services provided by banks as the essential thing in the Islamic banking industry. Levesque and McDougall (1996) explained that banking customer satisfaction attempts to satisfy bank customers by providing innovative ways. According to Wallin Andreassen and Lindestad (1998), Mohsan et al. (2011), and Sondakh (2014) that there is a positive and significant influence between Customer Satisfaction and Customer Loyalty. that the higher the level of satisfaction felt by the customer, the higher the loyalty level.

H3: Customer satisfaction has a positive effect on loyalty customer

\section{The effect of spiritual well-being on loyalty customer}

Spiritual conceptualization well-being includes constructs of vertical dimensions and horizontal dimensions. Religion as a vertical dimension shows well being individually relate to Allah or the power of the Highest (religious well-being). Social psychology as a horizontal dimension focuses on how well a person adjusts to the community and surrounding environment (existential well-being). According to Fatmah (2005) and Khan (2015), spiritual well-being and religiosity satisfy customers. Customers often associate choices about the principles of religious life in determining the type of products and services they will use. The religiosity of customers is very informed of their decision in determining the choice of products or services used. This principle of religiosity will bind customers in line with their beliefs. Satisfaction with sharia values can bind customer loyalty to continue to use the company's products or services. if the spiritual level of well-being and religiosity of a customer is high, then the level of loyalty will also be high

H4: Spiritual well-being has a positive effect on loyalty customer 


\section{The effect of religious commitment on loyalty customer}

Commitment is motivation and engagement as well as performance and compliance with the organization. According to Achsien (2000), religion contains everything that is best that man needs to determine the purpose of life. Religion provides happiness and prosperity, justice, and what is needed by a human. Religious commitment is participation or support for an organized society's practices, beliefs, attitudes, or sentiments. The religiosity dimension consists of the intrapersonal dimension (cognitive) and the interpersonal dimension (behavioral). The intrapersonal (cognitive) dimension focuses on an individual's beliefs or one's religious experience. The interpersonal (behavioral) dimension focuses on the level of activity in the activities of religious organizations (Worthington et al. 2003). According to El Junusi (2009), Sari (2011), and Sungkawa (2014) stated that religious commitment positively affects customer loyalty. The better the level of religious commitment of a person will increase satisfaction, so loyalty is also higher.

H5: religious commitment has a positive effect on loyalty customer

\section{Research model}

Based on the literature review and hypothesis formulation, the research model is presented in figure 1 .

Figure 1. Research model

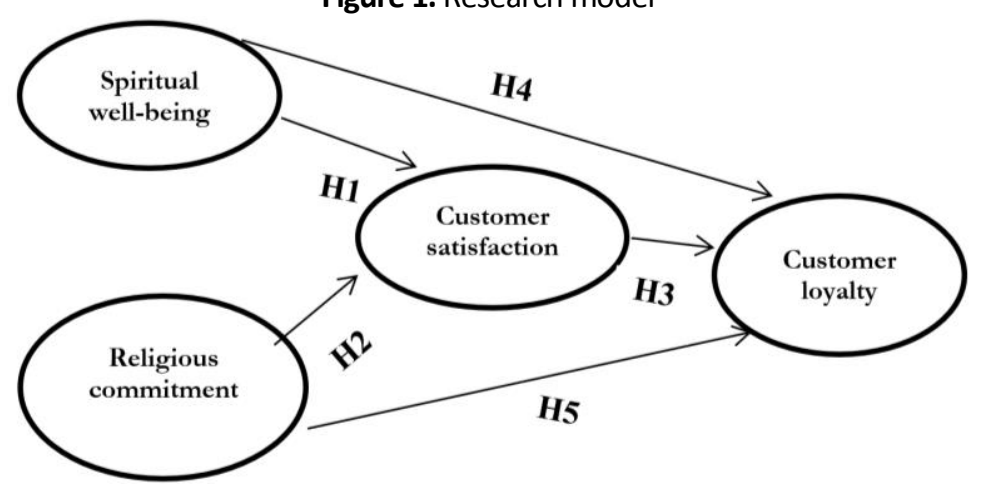

Economica: Jurnal Ekonomi Islam - Volume 12, Nomor 1 (2021) https://journal.walisongo.ac.id/index.php/economica 


\section{Methods}

\section{Data and samples}

This type of research uses primary data. The data is a questionnaire with a total of 165 respondents. The sample in this study is sharia banking customers in Semarang.

\section{Data analysis methods}

Data analysis used in this study is quantitative data, a form of analysis using numbers and calculations with statistical tools. Research requires data analysis and interpretation to answer questions in the study so that data analysis can be more read and interpreted. Hypothesis testing using the SPSS program. This study uses a path analysis model or referred to as path analysis.

The following forms of mathematical equations of multiple linear regression in this study are:

Model path 1

$$
\mathrm{Y}_{1}=\alpha+\beta_{1} \mathrm{X}_{1}+\beta_{2} \mathrm{X}_{2}+\mathrm{e} 1
$$

Model path 2

$$
\mathrm{Y}_{2}=\alpha+\beta_{1} \mathrm{X}_{1}+\beta_{2} \mathrm{X}_{2}+\beta_{3} \mathrm{Y}_{1}+\mathrm{e} 2
$$

Information :

$\mathrm{Y}_{2}=$ customer loyalty

$\alpha=$ constant

$\beta_{1}, \beta_{2} \beta_{3} \quad=$ regression coefficient

$\mathrm{X}_{1}=$ spiritual well-being

$\mathrm{X}_{2}=$ religious commitment

$\mathrm{Y}_{1}=$ customer satisfaction

$\mathrm{e} 1, \mathrm{e} 2=$ error 
Spiritual Well-Being and Religious Commitment in Explaining ...

\section{Operational definitions}

\section{Spiritual well-being}

Spiritual well-being conceptualization includes a two-dimensional construct consisting of vertical dimensions and horizontal dimensions. Religion as a vertical dimension shows well being individually associate with God or the Highest power. Social psychology as a horizontal dimension focuses on how well one adjusts to the community and the surrounding environment (existential well-being) (Imam, Abdul Karim, Jusoh, Mamad). Indicators: Subjective faith, Self-satisfaction, Personal Piety, and Optimism.

\section{Religious commitment}

The measurement of religious commitment refers to the scale of Worthington's religious commitments. Religious commitment is participation or support for an organized society's practices, beliefs, attitudes, or sentiments. In this study, the religiosity dimension consisted of the intrapersonal (cognitive) and interpersonal dimension (behavioral). The intrapersonal (cognitive) dimension focuses on an individual's beliefs or one's religious experience. The interpersonal (behavioral) dimension focuses on the level of activity in the activities of religious organizations (Worthington et al. 2003). Indicators: Visit places of worship, Gain inner peace of mind, level of personal religious beliefs, be Active in religious organization activities, and Make financial contributions to religious organizations.

\section{Customer satisfaction}

Satisfaction is a post-consumption evaluation where an alternative chosen meets or exceeds expectations or Customer satisfaction results from various efforts to attract customers (Martín-Consuegra, Molina, and Esteban 2007). Indicators: suitability of expectations, perception of performance, customer assessment, quality of service, and quality of products. 


\section{Customer loyalty}

Loyalty is a customer's commitment to a brand based on a very positive nature in long-term purchases. That loyalty to the brand is of the combination of satisfaction and complaints. At the same time, customer satisfaction is present from how much performance of the company to cause such satisfaction by minimizing complaints so that long-term purchases made by consumers (Tjiptono 2005). Indicators: repurchase, buying between product lines or services, recommending to others, and sure the brand is the best.

\section{Result and discussion}

Hypothesis tests are to determine whether or not independent variables affect dependent variables as table 1 .

Table 1. Classical assumption test

\begin{tabular}{lll}
\hline Independent Variable & & \\
\hline Multikolonierity Test & Tolerance & VIF \\
Spiritual well-being & 0,648 & 1,543 \\
Religious commitment & 0,689 & 1,452 \\
Customer satisfaction & 0,679 & 1,474 \\
\hline Heterokedastisity Test (Glejser test) & Sig t-test & \\
\hline Spiritual well-being & 0,511 & \\
Religious commitment & 0,070 & \\
Loyalty customer & 0,990 & \\
Auto correlation test (Run test) & 0,585 & \\
Normality residual test & & \\
Kolmogorov-Smirnov test & 0,200 & \\
\hline
\end{tabular}


Table 2. Test model - 1

\begin{tabular}{lrrr}
\hline $\begin{array}{l}\text { Independent Variable } \\
\text { Hypothesis Tes }\end{array}$ & coefficients & t value & sig \\
\hline Constant & 7,393 & 3,932 & 0,000 \\
Spiritual well-being & 0,388 & 4,988 & 0,000 \\
Religious commitment & 0,301 & 3,721 & 0,000 \\
\hline R square & 0,567 & & \\
Adjusted R square & 0,321 & & \\
F statistc & 38,376 & & \\
Sig F statistic & 0,000 & & \\
\hline
\end{tabular}

Dependent variable: Customer satisfaction

\section{Model-1: A path analysis}

To test the effect of independent variables on dependent variables using multiple linear regression analysis tests. For example, based on the calculation using SPSS 23 program obtained the following regression results as table 2:

\section{Model-2: A Path analysis}

To test the effect of independent variables on dependent variables using multiple linear regression analysis tests. For example, based on the calculation using SPSS 23 program obtained the following regression results as table 3 :

Table 3. Test Model - 2

\begin{tabular}{lrrl}
\hline $\begin{array}{l}\text { Independent Variable } \\
\text { Hypothesis Tes }\end{array}$ & & & \\
\hline Constant & 3,968 & 2,030 & 0,044 \\
Spiritual well-being & 0,325 & 3,913 & 0,000 \\
Religious commitment & 0,146 & 1,742 & 0,083 \\
Customer satisfaction & 0,117 & 2,497 & 0,036 \\
\hline R square & 0,502 & & \\
Adjusted R square & 0,252 & & \\
F statistc & 18,073 & & \\
Sig F statistic & 0,000 & & \\
\hline
\end{tabular}

Dependent variable: Loyalty customer

Economica: Jurnal Ekonomi Islam - Volume 12, Nomor 1 (2021) 
Figure 2. Path analysis model

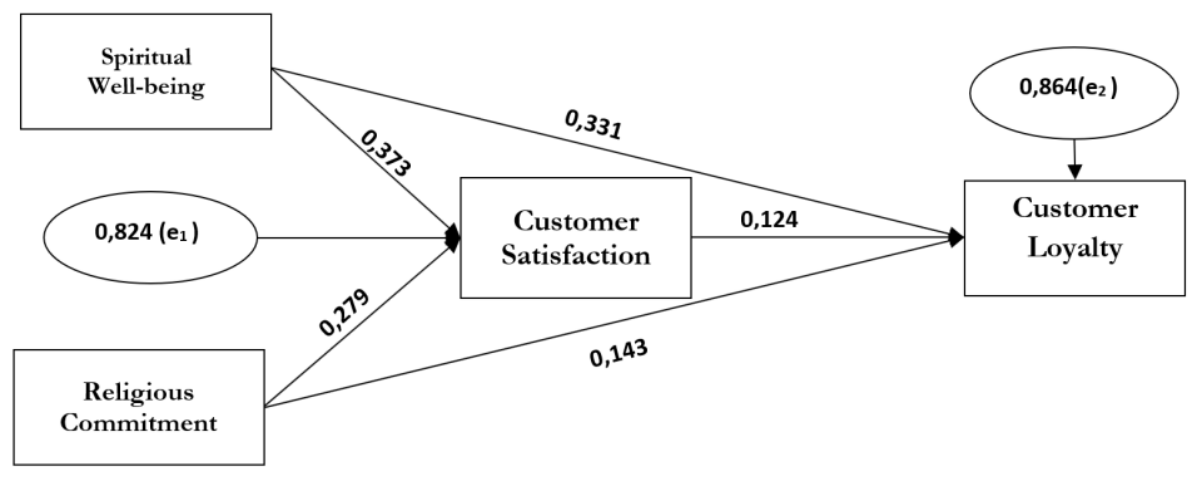

\section{Path Analysis Model}

The figure 2 describes the direct and indirect effect of independent variables (spiritual well-being and religious commitment) on dependent variables (customer loyalty) through intervening variables (customer satisfaction).

\section{The effect of spiritual well-being on customer satisfaction}

Based on the above regression results, spiritual well-being has a positive coefficient with t- the value of 4,988 and a significance level of 0.000 less than 0.05 , then Hypothesis 1 is accepted. So the conclusion is that spiritual wellbeing has a positive and significant effect on customer satisfaction.

Spiritual well-being is a good, safe and peaceful state. Spiritual well-being conceptualization includes a two-dimensional construct consisting of vertical and horizontal dimensions. Religion as a vertical dimension shows well-being individually related to Allah. In contrast, the horizontal dimension relates to human sesame, how well one adjusts to the group and environment. The results of this study following the research Fatmah (2005) and Khan (2015) stated that spiritual well-being and religiosity satisfy the customer. Customers often associate choices about the principles of religious life in determining the 
type of products and services they will use. Therefore, the religiosity of customers is very informed of their decision in determining the choice of products or services used. This principle of religiosity will bind customers in line with their beliefs so that satisfaction with sharia values can bind customer loyalty to continue to use the company's products or services. The higher the spiritual well-being level owned by a customer, the higher the level of satisfaction.

\section{The effect of religious commitment on customer satisfaction}

Based on the above regression results, religious commitment has a positive coefficient with a t-value of 3,721 and a significance level of 0.000 less than 0.05 , then Hypothesis 2 is accepted. So the conclusion is that religious commitment has a positive and significant effect on customer satisfaction.

The results of this study following the research Achsien (2000) religion contains everything that humans best need to determine the purpose of life. Religion gives happiness and prosperity, justice, and what is needed by man. Religious commitment is a form of adherence to religious teachings. According to El Junusi (2009), Sari (2011), and Sungkawa (2014) stated that religious commitment has a positive and significant influence on customer loyalty means that the higher the degree of religious commitment that customers have, the higher the satisfaction felt.

\section{The effect of customer satisfaction on loyalty customer}

Based on the above regression results, customer satisfaction has a positive coefficient with an at-value 2,497 and a significance level of 0.000 less than 0.05 , then Hypothesis 3 is accepted. So the conclusion is that customer satisfaction has a positive and significant effect on loyal customers.

According to Kotler and Amstrong (2004), customer satisfaction is how the product's performance (perceived performance) will follow customer expectations. At the same time, Oly Ndubisi (2004) said that customers place 
customer satisfaction criteria on the quality of services provided by banks as the essential thing in the Islamic banking industry. Furthermore, Levesque and McDougall (1996) explained that banking customer satisfaction attempts to satisfy bank customers by providing innovative ways. The results of this study support the research of Wallin Andreassen and Lindestad (1998), Mohsan et al. (2011), and Sondakh (2014), which suggests that there is a positive and significant influence between Customer Satisfaction and Customer Loyalty. Satisfaction is a post-consumption evaluation where an alternative chosen at least meets or exceeds expectations. The higher the level of satisfaction felt by the customer, the higher the level of loyalty.

\section{The effect of spiritual well-being on loyalty customer}

Based on the above regression results showed that spiritual well-being has a positive coefficient with a t-value of 3,913 and a significance level of 0.000 less than 0.05 then Hypothesis 4 is accepted. So the conclusion is that spiritual well-being has a positive and significant effect on loyal customers. Spiritual conceptualization well-being includes constructs of vertical dimensions and horizontal dimensions. Religion as a vertical dimension shows well being individually relate to Allah or the power of the Highest (religious well-being). Social psychology as a horizontal dimension focuses on how well a person adjusts to the community and surrounding environment (existential well-being). According to Fatmah (2005) and Khan (2015), spiritual well-being and religiosity satisfy the customer. Customers often associate choices about the principles of religious life in determining the type of products and services they will use. Therefore, the religiosity of customers is very informed of their decision in determining the choice of products or services used. This principle of religiosity will bind customers in line with their beliefs so that satisfaction with sharia values can bind customer loyalty to continue to use the company's products or services. If a customer's spiritual level of well-being and religiosity is high, loyalty will also be high. 
Spiritual Well-Being and Religious Commitment in Explaining ...

\section{The effect of religious commitment on loyalty customer}

The regression results showed that religious commitment has a positive coefficient with a t-value of 1,742 and a significance level of 0.083 , more than 0.05 but less than 0,10 . Then Hypothesis 5 is accepted. So the conclusion is that that religious commitment has a positive effect on loyal customers. Commitment is motivation and engagement as well as performance and compliance with the organization. According to Achsien (2000), religion contains everything that is best that man needs to determine the purpose of life. Religion provides happiness and prosperity, justice, and what is needed by a human. Religious commitment is participation or support for an organized society's practices, beliefs, attitudes, or sentiments. The religiosity dimension consists of the intrapersonal dimension (cognitive) and the interpersonal dimension (behavioral). The intrapersonal (cognitive) dimension focuses on an individual's beliefs or one's religious experience. The interpersonal (behavioral) dimension focuses on the level of activity in the activities of religious organizations (Worthington and Hight 2003). According to El Junusi (2009), Sari (2011), and Sungkawa (2014) stated that religious commitment positively affects customer loyalty. The better the level of religious commitment of a person will increase satisfaction, so loyalty is also higher.

\section{Conclusion}

Based on the above analysis results, conclusions in this study are that spiritual well-being has a positive and significant effect on customer satisfaction. Mean that spiritual well-being and religiosity can provide satisfaction to customers. The higher the spiritual well-being level possessed by a customer, the higher the level of satisfaction. Religious commitment has a positive and significant effect on customer satisfaction. Religion contains everything that is best that man needs to determine the purpose of life. Religion gives happiness and prosperity, justice, and what is needed by man. Religious commitment is a form of adherence to religious teachings. 
Alternatively, in other words, the higher the degree of religious commitment of the customer, the higher the satisfaction felt. Customer satisfaction has a positive and significant effect on loyal customers means that the higher the level of satisfaction felt by the customer, the higher the loyalty level. Spiritual well-being has a positive and significant effect on the loyal customer. If the spiritual level of well-being and religiosity is high, then loyalty will also be high. And then religious commitment has a positive and significant effect on loyalty customer means religion contains everything that is best that man needs to determine the purpose of life. The higher the level of religious commitment of the customer, the greater the level of customer loyalty.

Some suggestions for further research are to add variables and samples such as Islamic product attributes, quality of service, trust. Then further research should use objects other than Sharia banking so that it can describe this topic.

\section{References}

Achsien, Iggi H. 2000. Investasi Syariah Di Pasar Modal. Jakarta: Gramedia Pustaka Utama.

Chusnah, Nidaul. 2016. "Pengaruh Religiusitas, Kualitas Pelayanan, Dan Kepuasan Nasabah Terhadap Loyalitas Nasabah Bank Muamalat Indonesia KCP Magelang." IAIN Salatiga.

Fatmah. 2005. "Pengaruh Persepsi Religiusitas, Kualitas Layanan, Dan Inovasi Produk Terhadap Kepercayaan Dan Komitmen Serta Loyalitas Nasabah Bank Umum Syariah Di Surabaya." Universitas Airlangga Surabaya.

Hansemark, Ove C., and Marie Albinsson. 2004. "Customer Satisfaction and Retention: The Experiences of Individual Employees." Managing Service Quality: An International Journal 14 (1): 40-57. https://doi.org/10.1108/09604520410513668.

Junusi, Rahman El. 2009. “Pengaruh Atribut Produk Islam. Komitmen Agama. Kualitas Jasa Dan Kepercayaan Terhadap Kepuasan Dan Loyalitas Nasabah Bank Syariah (Pada Bank Muamalat Kota Semarang)." In Annual Conference on Islamic Studies (ACIS), 2-5. 
Kasmir. 2007. “Manajemen Perbankan.” In. Jakarta: PT. Raja Grafindo Persada.

Khan. 2015. "Pengaruh Religiusitas Dan Kepuasan Terhadap Loyalitas Nasabah Bank Syariah Di Surabaya Dengan Anteseden Kualitas Layanan." Sekolah Tinggi Ilmu Ekonomi Perbanas, Surabaya.

Kotler, Philip, and Gary Amstrong. 2004. Dasar-Dasar Pemasaran Edisi Kesembilan Jilid 1. Edited by Alexander Sindoro. 9th ed. Jakarta: PT Indeks.

Levesque, Terrence, and Gordon H.G. McDougall. 1996. "Determinants of Customer Satisfaction in Retail Banking." International Journal of Bank Marketing $14 \quad$ (7): 12-20. https://doi.org/10.1108/02652329610151340.

Martín-Consuegra, David, Arturo Molina, and Águeda Esteban. 2007. "An Integrated Model of Price, Satisfaction and Loyalty: An Empirical Analysis in the Service Sector." Edited by Hooman Estalami. Journal of Product \& Brand Management $16 \quad$ (7): 459-68. https://doi.org/10.1108/10610420710834913.

Mohsan, Faizan, Muhammad Musarrat Nawaz, M. Sarfraz Khan, Zeeshan Shaukat, and Numan Aslam. 2011. "Impact of Customer Stisfaction on Customer Loyalty and Intention to Switch: Evidence from Banking Sector of Pakistan." International Journal of Bussiness and Social Science 2 (16): 263-70.

https://ijbssnet.com/journals/Vol_2_No_16_September_2011/30.pdf.

Oly Ndubisi, Nelson. 2004. "Understanding the Salience of Cultural Dimensions on Relationship Marketing, It's Underpinnings and Aftermaths." Cross Cultural Management: An International Journal 11 (3): 70-89. https://doi.org/10.1108/13527600410797855.

Paloutzian, R F. 1997. "Spiritual Well-Being: A Psychological Perspective." Aging \& Spirituality, $I X, 1-3$.

Pangarso, Prastyono Putro. 2018. “Analisis Pengaruh Kualitas Pelayanan Dan Religiusitas Terhadap Kepuasan Dan Loyalitas Nasabah Koperasi Simpan Pinjam Dan Pembiayaan Syariah (KSPPS) Di Yogyakarta." Universitas Islam Indonesia Yogyakarta.

Parasuraman, A., Valarie A. Zeithaml, and Leonard L. Berry. 1985. "A Conceptual Model of Service Quality and Its Implications for Future 
Arif Afendi and Abdul Ghofur

Research." Journal of Marketing 49 (4): 41-50. https://doi.org/10.1177/002224298504900403.

Perlman, David. 1982. Loneliness: A Sourcebook of Current Theory, Research and Therapy. Vol. 36. John Wiley \& Sons Incorporated.

Putri, Aditya Lisa. 2017. "Pengaruh Atribut Produk Islam, Komitmen Agama, Kualitas Jasa Dan Kepercayaan Terhadap Kepuasan Nasabah Bank Syariah (Studi Kasus Pada KJKS BMT Dana Mulia Mangu)." Institut Agama Islam Negeri Surakarta.

Sari, Armida. 2011. "Pengaruh Atribut Produk Islam, Komitmen Agama, Kualitas Jasa Dan Kepercayaan Terhadap Kepuasan Nasabah PT. BPRS Puduarta Insani Tembung." Program Pascasarjana IAIN Sumatera Utara.

Sondakh, Conny. 2014. "Kualitas Layanan, Citra Merek, Dan Pengaruhnya Terhadap Kepuasan Nasabah Dan Loyalitas Nasabah Tabungan (Studi Pada Nasabah Taplus BNI Cabang Manado)." Jurnal Riset Bisnis Dan Manajemen 13: https://ejournal.unsrat.ac.id/index.php/jrbm/article/view/7525.

Sungkawa, Eyang. 2014. "Pengaruh Komitmen Agama Dan Kepercayaan Terhadap Loyalitas Nasabah Dan Kepuasan Nasabah Sebagai Variabel Intervening Pada Nasabah Tabungan Bank Syariah Mandiri KCP Painan." Program Pascasarjana Universitas Bung Hatta.

Tjiptono, F. 2005. "Pemasaran Jasa." In , 1st ed. Yogyakarta: Bayumedia Publishing.

Wallin Andreassen, Tor, and Bodil Lindestad. 1998. "Customer Loyalty and Complex Services: The Impact of Corporate Image on Quality, Customer Satisfaction and Loyalty for Customers with Varying Degrees of Service Expertise." International Journal of Service Industry Management 9 (1): 723. https://doi.org/10.1108/09564239810199923.

Worthington, Everett L., Nathaniel G. Wade, Terry L. Hight, Jennifer S. Ripley, Michael E. McCullough, Jack W. Berry, Michelle M. Schmitt, James T. Berry, Kevin H. Bursley, and Lynn O'Connor. 2003. "The Religious Commitment Inventory--10: Development, Refinement, and Validation of a Brief Scale for Research and Counseling." Journal of Counseling Psychology 50 (1): 84-96. https://doi.org/10.1037/0022-0167.50.1.84.

Zeithaml, Valarie A, and Mary Jo Bitner. 2013. Services Marketing: Integrating Customer Focus across the Firm. 3rd ed. Boston: McGraw-hill. 